RESEARCH ARTICLE

\title{
A Comparative Evaluation of Community Periodontal Index (CPI) and the Presence of Nicotine Stomatitis among Smokers after Oral Hygiene Instruction
}

\author{
Meta Maulida Damayanti, ${ }^{1}$ Yuktiana Kharisma, ${ }^{2}$ Fajar Awalia Yulianto, ${ }^{3}$ Santun \\ Bhekti Rahimah, ${ }^{2}$ Winni Maharani, ${ }^{4}$ Meike Rachmawati, ${ }^{1}$ Herri S. Sastramihardja, ${ }^{2}$ \\ Muhammad Alief Abdul 'Aziiz, ${ }^{5}$ Muhammad Ilham Halim \\ ${ }^{1}$ Department of Pathology, ${ }^{2}$ Department of Pharmacology, ${ }^{3}$ Department of Public Health, \\ ${ }^{4}$ Department of Microbiology, ${ }^{5}$ Medical Undergraduate Study Program, Faculty of Medicine, \\ Universitas Islam Bandung, Bandung, Indonesia
}

\begin{abstract}
Smoking can cause periodontal disease as well as lesions in the oral mucosa. Nicotine stomatitis is inflammation caused by heat stimuli injury on the hard and soft palate of the oral cavity; smokers commonly suffer from this condition. Knowledge of how oral hygiene affects the health of dental and oral cavity. The purpose of this study was to describe the differences in community periodontal index (CPI) and nicotine stomatitis in smokers after oral hygiene instruction. The study subjects were 54 men who have a history of active smoking for more than five years. The experiment was carried out in the Biomedical Laboratory of Faculty of Medicine Universitas Islam Bandung in September 2018-January 2019. Dental examination initiated before and after dental health instructions. CPI and nicotine stomatitis tests performed on all subjects by dentists using dental instruments. After six weeks of information about oral hygiene, all subjects re-examined. The results show that there is a statistically significant difference in the average CPI value in smokers before and after dental instruction with a $p$ value $<0.001(p \leq 0.05)$. In contrast, the condition of nicotine stomatitis remains the same. CPI value influenced by oral and dental hygiene showed that dental health instruction is very effective. However, stomatitis has not healed as long as the cause is not eliminated.
\end{abstract}

Key words: Community periodontal index, smokers, stomatitis nicotine

\section{Evaluasi Komparatif Community Periodontal Index (CPI) dan Stomatitis Nikotin di Kalangan Perokok setelah Instruksi Kebersihan Mulut}

\begin{abstract}
Abstrak
Merokok dapat menyebabkan penyakit pada periodontal maupun lesi pada mukosa mulut. Stomatitis nikotin merupakan inflamasi yang disebabkan oleh panas yang terdapat pada palatum keras dan lunak; perokok umumnya menderita kondisi ini. Pengetahuan mengenai tata cara kebersihan mulut memengaruhi kesehatan gigi dan rongga mulut. Tujuan penelitian ini menilai perbedaan community periodontal index (CPI) dan stomatitis nikotin pada perokok setelah instruksi kebersihan mulut. Subjek penelitian adalah 54 pria yang memiliki riwayat merokok aktif selama lebih dari lima tahun. Penelitian dilakukan di Laboratorium Biomedik, Fakultas Kedokteran, Universitas Islam Bandung pada bulan September 2018-Januari 2019. Pemeriksaan dental dilakukan sebelum dan setelah instruksi kesehatan gigi. Pemeriksaan CPI dan stomatitis nikotin dilakukan kepada seluruh subjek oleh dokter gigi menggunakan instrumen gigi. Setelah enam minggu mendapatkan penyuluhan mengenai kebersihan mulut, seluruh subjek diperiksa kembali. Hasil penelitian menunjukkan bahwa terdapat perbedaan bermakna secara statistik nilai CPI rerata pada perokok sebelum dengan setelah dilakukan instruksi kesehatan gigi dengan p<0,001 $(\mathrm{p} \leq 0,05)$. Sebaliknya, kondisi stomatitis nikotin tetap sama. Nilai CPI dipengaruhi oleh kebersihan gigi dan mulut sehingga instruksi kesehatan gigi sangat efektif. Akan tetapi, stomatitis tidak dapat sembuh selama penyebabnya tidak dihentikan.
\end{abstract}

Kata kunci: Community periodontal index, perokok, stomatitis nikotin

Received: 12 April 2020; Revised: 19 April 2020; Accepted: 21 April 2020; Published: 30 April 2020

Correspondence: Meta Maulida Damayanti, drg., M.Kes. Department of Pathology, Faculty of Medicine, Universitas Islam Bandung. Jln. Tamansari No. 22, Bandung 40116, West Java, Indonesia. E-mail: meta_md@unisba.ac.id 


\section{Introduction}

Smoking with tobacco increases the possibilities of periodontal disease by affecting periodontal attachment, pocket formation, and bone loss. Besides, smoking will cause inflammation on the gingiva, and cause stains on the teeth interfere with the aesthetics and halitosis. ${ }^{1-3}$ Smoking also causes damage to almost all organs and body systems. Oral health is an area that receives less attention, but it is a vital area. If the normal flora of the mouth changes, it will cause various diseases, both local and systemic. The smoke of the cigarette can cause the oral mucosal epithelium to be susceptible to the pathogen. ${ }^{4}$ Periodontal disease often occurs, and there are some risk factors such as smoking, the knowledge of dental health, socioeconomic status, diabetes, senility, heredity, genetics, oral hygiene, lifestyle, and stress are related to periodontal disease. ${ }^{.-7}$

Cigarettes have a hazardous composition such as gas, nicotine, tar, and also contains more than 4,000 chemical constituents. Nicotine and tar able to stimulate injuries that will cause changes in the oral cavity such as changes in $\mathrm{pH}$ of the oral cavity, oral moisture, increasing intraoral temperature, changing immune response, and resistance to infections, especially fungal and virus infections. ${ }^{2,8}$

Nicotine stomatitis is a lesion that formed due to physical irritation from smoke. ${ }^{9}$ The temperature at the tip of the tobacco cigarette combustion reaches $650^{\circ} \mathrm{C}\left(470^{\circ} \mathrm{C}-812^{\circ} \mathrm{C}\right)$, and the core temperature of the cigarette can reach $824^{\circ} \mathrm{C}-897^{\circ} \mathrm{C}$. During inhalation of smoke, the mouth can reach $190^{\circ} \mathrm{C}$. High-temperature fumes that come into direct contact with the mucous palate causing irritation and inflammation of the minor salivary glands in the hard palate. ${ }^{2}$

Periodontal screening is to prevent periodontal disease and improve oral health. Community periodontal index (CPI) or periodontal screening record should be performed for assessing the periodontal tissue. ${ }^{10-12}$

Instructions on oral hygiene such as tooth brushing techniques, frequency, and time of brushing are essential knowledge to improve dental and oral hygiene and health. The research aimed to see how the prevalence of nicotine stomatitis and the value of CPI in smokers after oral hygiene instruction that is needed to detect severe periodontal disease.

\section{Methods}

The study was at the Biomedical Laboratory, Faculty of Medicine, Universitas Islam Bandung (Unisba), from September 2018 to January 2019. Subjects were Unisba security officers with inclusion criteria, adults aged over 20 years, and a history of active smoking for more than five years. The research subjects were 54 men. The method is by examining the periodontal health status based on the criteria of the CPI and lesions on the palate that is nicotine stomatitis before and after instructions regarding dental and oral hygiene. CPI examination by evaluating the community periodontal index treatment needs (CPITN) as follows; Code o to Code 4 (Code o: healthy periodontal conditions; Code 1: gingival bleeding on probing; Code 2: calculus and bleeding; Code 3 : periodontal sac 4-5 $\mathrm{mm}$; and Code 4: periodontal sac $\geq 6 \mathrm{~mm}$ ). Nicotine stomatitis examination is done with anamnesis and examination using a mouth glass by the dentist. ${ }^{10,13}$

The data were processed using SPSS, and differences in CPI values analyzed with the Wilcoxon signed ranks test while for nicotine stomatitis analyzed with a chi-square test. The data presented in tabular form. The Health Research Ethics Committee of Faculty of Medicine Universitas Islam Bandung has approved this research, with the ethical clearance number: 379/ Komite Etik.FK/X/2018.

\section{Results}

A total of 54 subjects were included in this study, had an average age of 34 years, with $74 \%$ had a history of having a toothache.

Table 1 shows that before oral hygiene instructions, most smokers in Code 1 as much as 37 people $(68 \%)$, whereas after instruction, most in Code $\mathrm{o}$ as much as 45 people (83\%). The results of the analysis using the Wilcoxon signed ranks test at $95 \% \mathrm{CI}$ that there are statistically significant differences in the average CPI value in smokers before and after oral hygiene instruction at Unisba, with a p value $<0.001(\mathrm{p} \leq 0.05)$.

Table 2 shows stomatitis in smokers before and after oral hygiene instruction. Before oral hygiene instructions, most smokers experience stomatitis as much as 37 people (69\%), while after instructions, most smokers also experience stomatitis are 35 people (65\%). 
Table 1 Differences of Average in CPI Values of Smokers before and after Oral Hygiene Instruction

\begin{tabular}{lccl}
\hline \multirow{2}{*}{ CPI Values } & \multicolumn{2}{c}{ Groups (n=54) } & \multirow{2}{*}{ p Value $^{*}$} \\
\cline { 2 - 3 } & Before & After & \\
\hline CPI codes & & & \\
Code 0 & $15(28 \%)$ & $45(83 \%)$ & \\
Code 1 & $37(68 \%)$ & $8(15 \%)$ & \\
Code 2 & $2(4 \%)$ & $1(2 \%)$ & \\
CPI value & & & $<0.001$ \\
$\quad$ Average (SD) & $0.76(0.51)$ & $0.19(0.43)$ & \\
Median (min-max) & $1(0-2)$ & $0(0-2)$ & \\
\hline
\end{tabular}

Note: "Wilcoxon signed ranks test; Code o: healthy periodontal conditions; Code 1: gingival bleeding on probing; Code 2: calculus and bleeding

Table 3 shows smokers with stomatitis before and after instruction. They were 35 people (95\%), while smokers without stomatitis before counseling with stomatitis after instruction were none (o\%). Stomatitis before and after the instruction found in two people (5\%), while subjects without stomatitis before and after instruction were 17 people (100\%).

Based on Table 3, the results of the chi-square test with the $95 \% \mathrm{CI}$ indicate that there were no statistically significant differences in smokers who experience stomatitis before and after

Table 2 Overview of Nicotine Stomatitis in Smokers before and after Oral Hygiene Instruction

\begin{tabular}{lcc}
\hline \multirow{2}{*}{ Stomatitis } & \multicolumn{2}{c}{ Groups (n=54) } \\
\cline { 2 - 3 } & Before & After \\
\hline Yes & $37(69 \%)$ & $35(65 \%)$ \\
No & $17(31 \%)$ & $19(35 \%)$ \\
\hline
\end{tabular}

oral hygiene instruction with $\mathrm{p}$ value $=0.500(\mathrm{p}$ value $>0.05$ ).

\section{Discussion}

Smoking is a significant risk factor associated with a lifestyle that causes periodontal disease. Oral hygiene instruction is the most effective way to change people's behavior regarding the importance of oral and dental hygiene, starting with proper technique, frequency, and time of brushing. ${ }^{14}$

This study shows that the periodontal disease that is assessed by CPI before the oral and dental health instruction is higher than after the instruction, and it is useful for explaining the pathogenesis of periodontal disease caused by smoking. Sajjad et al. ${ }^{1}$ and Saribas et al. ${ }^{7}$ stated there is a high correlation between the consumption of tobacco and gingival index, the plaque index, and the community periodontal index of treatment needs, there was a high correlation between intake of tobacco and the gingival score.

Table 3 Differences in Nicotine Stomatitis Conditions in Smokers before and after Oral Hygiene Instruction

\begin{tabular}{|c|c|c|c|c|}
\hline \multirow{2}{*}{ Stomatitis before } & \multicolumn{2}{|c|}{ Stomatitis after } & \multirow{2}{*}{ Total (\%) } & \multirow{2}{*}{ p Value ${ }^{*}$} \\
\hline & Yes (\%) & No (\%) & & \\
\hline Yes (\%) & $35(95)$ & $2(5)$ & $37(100)$ & 0.500 \\
\hline No (\%) & $\mathrm{o}(\mathrm{o})$ & $17(100)$ & $17(100)$ & \\
\hline Total (\%) & $35(65)$ & $19(35)$ & $54(100)$ & \\
\hline
\end{tabular}

Note: McNemar test; " chi-square test 
Nicotine can inhibit alveolar bone repair. Smokers have periodontitis four times more than nonsmokers. In general, calculus deposits are higher and also gingival inflammation. ${ }^{15}$ The results showed that smoking is very susceptible to periodontal disease. Smoking affects the periodontitis process through an immunological mechanism and vascular damage. The periodontal status index and gingival melanin pigmentation were significantly worse in smokers than nonsmokers; it indicates that chronic smoking habits can affect dental health and can cause different periodontal disease. The level of gingival melanin pigmentation can correlate with worsening periodontal status and can be used as an early symptom of developing periodontal disease. ${ }^{16-18}$

History of stomatitis in the study showed no difference between before and after oral hygiene instruction. Mild nicotine stomatitis does not need therapy. However, if it worsens, it can be treated palliatively, giving the instructions for improving oral hygiene and stop smoking. ${ }^{2}$ Nicotine stomatitis is a keratosis in the palate caused by tobacco. Palatal mucosa initially appeared reddish. Furthermore, in the vicinity of the minor salivary gland ducts shows inflammation and dilated holes, many micronodules from the red punctate region forming and making diffuse grayish-white wrinkles. The epithelial lining of the oral mucosa is the first immune system to invading microorganisms and carcinogenic agents. ${ }^{19}$

Etiology of nicotine stomatitis increased because of the temperature, rather than the tobacco chemicals. The temperature is responsible for this lesion. Among elderly Indian and Thailandian people, the general oral mucosal lesion type is smoker's palate with an incidence of $43 \%$. Lesions mostly involve the maxillary hard palate region with a prevalence of $23.1 \% .^{19,20}$

During an intraoral examination, different oral lesions also recorded. The most common oral lesion was oral submucosal fibrosis, which affected $12.2 \%$ of subjects, followed by nicotine stomatitis (10.8\%). ${ }^{21}$ Other studies state that there are effects of smoking at different sites of the oral cavity and show the potential effects of smoking on buccal mucosal microbiota. ${ }^{22}$ The heterogeneity of the oral microbe ecosystem found can contribute to the stability of the oral microbiota in most locations, when environmental disturbances occurred, such as those caused by smoking. Research that is conducted by Ain et al. ${ }^{3}$ regarding various oral lesions where the subject has various bad habits; the most common is smoking (56.46 \%).

\section{Conclusions}

Smoking is closely related to the onset of periodontal disease. Assessment and diagnosis of periodontal conditions of a smoker is a complex and challenging task to prevent serious diseases. Instructions regarding effective oral hygiene can reduce the risk of periodontal disease but cannot cure nicotine stomatitis.

\section{Conflict of Interest}

There is no conflict of interest in this study.

\section{Acknowledgments}

The authors convey gratitude to all staff of Biomedical Laboratory staff of Faculty of Medicine, Universitas Islam Bandung.

\section{References}

1. Sajjad F, Mumtaz M, Ramsha Sajjad R. Effects of tobacco chewing and smoking and its relationship with periodontal health. Natl J Health Sci. 2017;2(3):106-8.

2. Prabowo DMS, Widodo HB. Nicotine stomatitis in smokers: a case report. J Dentomaxillofac Sci. 2018;3(1):58-60.

3. Ain TS, Gowhar O, Sultan S, Tangade P. Prevalence of oral mucosal lesions and associated habits in Kashmir, India. Int J Res Med Sci. 2016;4(8):3525-30.

4. Ozturk O, Fidanci $\dot{\mathrm{I}}$, Unal M. Effects of smoking on oral cavity. J Exp Clin Med. 2017;34(1):3-7.

5. Robbihi AI, Sulaeman ES, Rahardjo SS. Path analysis: the effect of smoking on the risk of periodontal disease. IJM. 2018;3(2):99-109.

6. Nazir MA. Prevalence of periodontal disease, its association with systemic diseases and prevention. Int $\mathrm{J}$ Health Sci (Qassim). 2017;11(2):72-80.

7. Saribas E, Acun Kaya F, Dogru AG, Yildirim TT. Determination of periodontal status and smoking habits with CPITN index. Int Dent Res. 2017;7(2):26-31.

8. Horinouchi T, Higashi T, Mazaki Y, Miwa 
S. Carbonyl compounds in the gas phase of cigarette mainstream smoke and their pharmacological properties. Biol Pharm Bull. 2016;39(6):909-14.

9. Visconti MJ, Ashack KA. Dermatologic manifestations associated with electronic cigarette use. J Am Acad Dermatol. 2019;81(4):1001-7.

10. Nomura Y, Okada A, Kakuta E, Gunji T, Kajiura S, Hanada N. A new screening method for periodontitis: an alternative to the community periodontal index. BMC Oral Health. 2016;16(1):64.

11. Kobayashi T, Suda T, Mizutani K, Aoyama N, Koyanagi T, Hayakumo S, et al. Clarification of quantitative intraoral circumstances with the community periodontal index of treatment needs data using covariance structure analysis. J Clin Diagn Res. 2019;13(6):ZC414.

12. Susanto A, Carolina DN, Amaliya A, Setia Pribadi IM, Miranda A. Periodontal health status and treatment needs of the community in Indonesia: a cross sectional study. J Int Oral Health. 2020;12(2):114-9.

13. Naz I, Butt AM, Bashir U, Memon $H$. Periodontal tissue; effect of fix orthodontic treatment. Prof Med J. 2017;24(6):930-4.

14. Amoo-Achampong F, Vitunac DE, Deeley K, Modesto A, Vieira AR. Complex patterns of response to oral hygiene instructions: longitudinal evaluation of periodontal patients. BMC Oral Health. 2018;18(1):72.

15. Handa S, Koui H, Khurana C. Insight into nicotine addiction. CHRISMED $J$ Health Res. 2017;4(2):69-75.
16. Goyal V, Devaraj GC. Correlation of smoking, periodontal health status and gingival melanin pigmentation. Int $J$ Health Sci Res. 2017;7(1):109-14.

17. Kubota M, Yanagita M, Mori K, Hasegawa S, Yamashita M, Yamada S, et al. The effects of cigarette smoke condensate and nicotine on periodontal tissue in a periodontitis model mouse. PLoS One. 20;11(5):e0155594.

18. Leite FRM, Nascimento GG, Scheutz F, López R. Effect of smoking on periodontitis: a systematic review and meta-regression. Am J Prev Med. 2018;54(6):831-41.

19. Koray M, Tosun T. Oral mucosal trauma and injuries. In: Gözler S, editor. Trauma in dentistry [e-book]. London: IntechOpen Limited; 2019 [cited 2020 January 30]. Available from: https://www.intechopen. com/books/trauma-in-dentistry/oralmucosal-trauma-and-injuries.

20. Regezi JA, Sciubba J, Jordan RCK. Oral pathology: clinical pathologic correlations. 7th Edition. Elsevier Health Sciences. St. Louis: Elsevier; 2017.

21. Alshayeb M, Mathew A, Varma S, Elkaseh A, Kuduruthullah S, Ashekhi A, et al. Prevalence and distribution of oral mucosal lesions associated with tobacco use in patients visiting a dental school in Ajman. Oncol Radiother. 2019;13(2):29-33.

22. Mushatat SF, Khalaf AA, Al-Deen Taher JM. A clinical study about oral lesions and normal variants of the oral mucosa. J Pharm Sci Res. 2018;10(7):1755-7. 